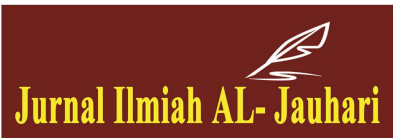

Jurnal Ilmiah ALo-Jauhari: Jurnal Studi Islam dan Interdisipliner

Volume 4 No 2, (Desember 2019): Halaman 261-282

ISSN (Print): 2541-3430, ISSN (Online): 2541-3449

Website: http://journal.iaingorontalo.ac.id/index.php/aj

\title{
Orientasi Perubahan Kurikulum Pendidikan Pesantren
}

\author{
Samsul Bahri \\ (IAIN Sultan Qaimuddin Kendari) \\ smsulbahri@gmail.com
}

\begin{abstract}
This study orientation changes in the pesantren education curriculum (case study of the Islamic boarding school of the Islamic Boarding School in Kendari. This study uses a field research instrument. The method used is descriptive-analytical with a sociological, historical, comparative approach. Ummushabri Kendari by opening MTS and MA as a modern education system.But the change caused the traditional education system abandoned by students, therefore, traditional pesantren education has lost its function as a pesantren institution, which instead is dominated by the madrasa curriculum and public schools. all pesantren make changes leaving their tradition, this can be seen from the renewal of the Lirboyo pesantren education which succeeded in maintaining the main function of the pesantren institution namely the transmission of Islamic science, the maintenance of Islamic traditions the creation of ulama cadres, and made the Lirboyo pesantren renewal model as a comparison.
\end{abstract}

\section{Abstrak}

Kajian ini berorientasi pada perubahan kurikulum pendidikan pesantren ummusshabri Kendari. Penelitian ini menggunakan instrument penelitian lapangan. Metode yang digunakan adalah 
deskriptif-analitis dengan pendekatan sosiologis, sejarah, komparatif. Penelitian ini membuktikan bahwa oreintasi perubahan kurikulum pesantren dalam perspektif historis telah dilakukan pesantren Ummushabri Kendari dengan membuka MTS dan MA sebagai sistem pendidikan modern. Namun perubahan itu menyebabkan sistem pendidikan tradisional ditinggalkan siswanya, karena itu, pendidikan tradisional pesantren telah kehilangan fungsinya sebagai lembaga pesantren, yang justru mendominasi adalah kurikulum madrasah dan sekolah umum. Studi ini juga menemukan tidak semua pesantren melakukan perubahan meninggalkan tradisinya, hal ini terlihat pembaharuan pendidikan pesantren Lirboyo yang berhasil mempertahankan fungsi utama lembaga pesantren yakni trasnmisi ilmu pengetahuan keislaman, pemeliharaan tradisi Islam serta penciptaan kader-kader ulama, dan menjadikan model pembaharuan pensantren Lirboyo sebagai perbandingan.

Kata Kunci: Kurikulum, Pendidikan, Pesantren

\section{Pendahuluan}

Kajian mengenai pendidikan formal, terutama yang terkait dengan proses belajar mengajar tidak bisa dipisahkan dari persoalan kurikulum. Kurikulum menjadi semacam barometer tersendiri berhasil tidaknya proses pengajaran. Yang perlu digarisbawahi adalah kurikulum tidak hanya identik dengan satuan mata pelajaran saja. Menurut Hilda Taba, seperti dikutip oleh S. Nasution, kurikulum tidak boleh didefinisikan terlalu luas namun juga tidak terlalu sempit. ${ }^{1}$

Semua aspek yang terkait dengan pendidikan seperti metode belajar, sasaran-sasaran pembelajaran, juga termasuk dalam lingkup kurikulum. Dengan merujuk kepada 'regulasi akademik' tersebut diharapkan proses pendidikan akan berjalan secara sistematis dan memiliki orientasi yang jelas. Sebab arah pendidikan di samping sebagai media peningkatan penguasaan pengetahuan, kemampuan, dan keterampilan, juga merupakan sarana pengembangan nilai-nilai normatif dalam rangka membentuk jati diri peserta didik. ${ }^{2}$ Bagaimanapun bentuk atau model suatu lembaga pendidikan termasuk jenis pesantren-, sudah barang tentu menempatkan kurikulum sebagai landasan penting proses belajar mengajar walaupun dalam aplikasi di tingkat institusi berbeda-beda karena disesuaikan

\footnotetext{
Cet. 2 , h. 7

${ }^{2}$ Nana Syaodih Sukmadinata, Landasan Psikologi Proses Pendidikan, (Bandung: PT. Remaja Rosdakarya, 2004), h. 4.
}

${ }^{1}$ S. Nasution, Asas-asas Kurikulum, (Jakarta: Bumi Aksara, 1995), Edisi. 2, 
dengan kondisi riil suatu lembaga. Meskipun pesantren selama ini dikenal konservatif dan identik dengan wilayah Islam tradisional, pada dasarnya pesantren tetap membuka diri bagi perubahan.

Perjumpaan pesantren ${ }^{3}$ dengan kurikulum merupakan sebuah keharusan karena kedudukannya yang cukup sentral dalam dunia keilmuan. Menurut Azyumardi Azra, karena kedudukannya sebagai lembaga pendidikan indigenous, pesantren memiliki akar sosiohistoris yang cukup kuat. Dengan bekal tersebut pesantren mampu bertahan di tengah gelombang perubahan berbagai sisi kehidupan menyangkut ekonomi, politik, sosial, dan budaya. Dalam konteks keilmuan, Azyumardi berpendapat paling tidak pesantren Memiliki tiga fungsi pokok. Pertama, transmisi ilmu pengetahuan Islam (transmission of Islamic knowledge); kedua, pemeliharaan tradisi Islam (maintenance of Islamic tradition); ketiga, pembinaan caloncalon ulama (reproduction of ulama). ${ }^{4}$

\section{Diskursus Teori Pesantren}

Ada dua teori utama dalam perdebatan tentang asal usul pesantren di Indonesia. Menurut Dhofier menyebut bahwa pesantren berasal dari tradisi pesantren Timur tengah, bukan asli dari Indonesia. Model pesantren yang ada di Jawa sekarang merupakan model gabungan antara madrasah dengan pusat tarekat yang ada di Timur Tengah. Demikian juga dengan Martin van Bruinessen dalam buku yang berjudul Kitab Kuning: Pesantren dan Tarekat, yang tidak

\footnotetext{
${ }^{3}$ Pesantren atau pondok adalah lembaga yang dapat merupakan wujud proses yang wajar perkembangan sistem pendidikan dan selanjutnya, ia dapat merupakan bapak dari pendidikan Islam. Karena itu dalam buku Sistem Pendidikan Pesantren Mastuhu mendefinisikan sebagai berikut: suatu lembaga pendidikan tradisional Islam untuk mempelajari, memahami, mendalami, menghayati dan mengamalkan ajaran Islam dengan menekankan pentingnya moral keagamaan sebagai pedoman prilaku sehari-hari. Pesantren sendiri menurut pengertian dasarnya adalah tempat belajar para santri. Sedangkan pondok berarti rumah atau tempat tinggal sederhana yang terbuat dari bambu. Di samping juga kata "pondok" juga berasal dari bahasa Arab "Funduq" yang berarti "Hotel atau asrama". Namun demikian, kelangsungan hidup suatu pesantren amat tergantung kepada daya tarik tokoh sentral (kiyai) yang memimpin, meneruskan atau mewarisinya. Oleh sebab itu jika membicarakan mengenai pesantren berarti praktis mempunyai ; pondok, mesjid, santri, kiai, serta kitab-kitab Islam klasik. Lihat Andi M. Ramli, Gambaran Singkat tentang Pendidikan di Pesantren, dala Buletin Bina Pesantren, Depag RI, Juli 1999, hlm. 6. Lihat Hasbullah, Sejarah Pendidikan Islam di Indonesia, Jakarta, Raja Grafindo Persada, 1999, h.138 Lihat Mastuhu, Dinamika Pendidikan Pesantren, Indonesia, Netherlands coorporation in Islamic Studies, seri Inis, XX, Jakarta, 1994, hlm. 55. Bandingkan dengan Zamakhsyari Dhofier, Tradisi Pesantren, (Jakarta, LP3ES, 2011), h. 18.

${ }^{4}$ Azyumardi Azra, Esei-esei Intelektual Muslim dan Pendidikan Islam, (Jakarta: Logos Wacana Ilmu, 1998), Cet.1, h. 87
} 
sepakat dengan argumen bahwa pesantren merupakan kelanjutan dari sistem pendidikan Hindu-Budha sebelum datangnya Islam ke Indonesia. Menurut Martin, Al-Azhar merupakan tipologi awal dari model pesantren yang ada di Indonesia.

Teori kedua menyatakan bahwa pesantren berasal dari tradisi pendidikan pra Islam atau pendidikan dalam tradisi Hindu Budha. Pendapat ini dikemukakan Manfried Zambek dalam buku Pesantren dan Perubahan Sosial. Menurutnya pola kelembagaan pesantren sekarang ini secara paralel merupakan kelanjutan dari lembaga pendidikan pra Islam yang sudah melembaga sebelumnya. Pendapat yang sama dikemukakan Nurcholish Madjid dalam buku Bilik-Bilik Pesantren: Sebuah Potret Perjalanan: mengakui bahwa pesantren yang ada sekarang ini merupakan kelanjutan dari pesantren era HinduBudha. Ketika Islam datang, tinggal memberi warna Islam pada lembaga pendidikan yang sudah ada.

Kedua teori di atas, memunculkan teori konvergensi menjadi acuan dalam melihat pesantren. Secara kelembagaan merupakan asimilasi dari model pendidikan luar baik pendidikan Islam di Timur Tengah maupun pendidikan Hindu-Budha yang masuk ke Indonesia. ${ }^{5}$ Ciri pesantren yang ada pada pendidikan Hindu-Budha dengan tradisi asrama dan mandala, sedangkan model pendidikan kitab kuning mengacu pada pendidikan Timur Tengah. ${ }^{6}$ Karena itu, teori tersebut saling melengkapi antara satu dengan yang lain.

\section{Pergumulan Pesantren dalam Perspektif Sejarah}

Dalam perspektif sejarah lembaga pesantren sudah ada sejak 300-400 tahun yang lalu dan telah mulai dikenal di bumi Nusantara ini dalam priode abad ke 13-17 M, dan di Jawa terjadi pada abad ke-15$17 \mathrm{M}^{7}$ Tetapi pesantren di Indonesia, menurut sebagian ahli, mulai berdiri sejak masa-masa permulaan Islam ke Indonesia. Meski tidak diketahui namanya. Pesantren yang dianggap paling tua di Indonesia adalah pesantren yang terletak di daerah Aceh. ${ }^{8}$ Akan tetapi, menurut tinjauan lain, yang dianggap sebagai pendiri pertama pondok

\footnotetext{
${ }^{5}$ Wakhid Khozin, Pendidikan Kewargaan Pada Komunitas Pesantren, (Jakarta: Prasasti, 2007), h. 5

${ }^{6}$ Hanun Asrohah, Pelembagaan Pesantren: Asal Usul dan Perkembangan Pesantren di Jawa, (Jakarta: Bagian Proyek Peningkatan Informasi Penelitian dan Diklat Keagamaan Departemen Agama RI. 2004), h. 5.

${ }^{7}$ Mastuhu, Dinamika Sistem Pendidikan Pesantren, h. 20

${ }^{8}$ Imron Arifin, Kepemimpinan Kiai: Kasus Pondok Pesantren Tebuireng, (Malang: kalimasahada, 1993), h. 17.
} 
pesantren adalah Syekh Maulana ${ }^{9}$ Malik Ibrahim (wafat 18 April 1419 M.) yang berasal dari Gujarat, India ${ }^{10}$

Menurut sumber yang lain, pesantren di Indonesia baru diketahui keberadaanya dan perkembangannya setelah abad ke-16. Banyak pesantren yang mengajarkan berbagai kitab Islam klasik dalam bidang fiqih, teologi dan tasawuf, ${ }^{11}$ dan sejarah telah mencatat, ribuan pesantren besar dan kecil, tumbuh berkembang dan akhirnya tergusur. Hal ini disebabkan karena daya tahan sebuah pesantren sangat bergantung pada besar-kecilnya kapasitas kiai sebagai pendiri, dan kesadaran tanggung jawab keturunannya. ${ }^{12}$ Menurut Ahmad Tafsir bahwa lembaga pesantren yang besar jumlahnya dan luas penyebarannya di berbagai pelosok tanah air telah banyak memberikan saham dalam pembentukan manusia Indonesia yang religius. Bahkan, lembaga tersebut telah banyak melahirkan pemimpin bangsa di masa lalu, kini, dan agaknya juga masa datang. Lulusan pesantren tak pelak lagi banyak yang mengambil partisipasi aktif dalam pembangunan bangsa. ${ }^{13}$

Pesantren dalam lintasan sejarah sangat berkaitan erat dengan sejarah Islam. Hal ini dibuktikan bahwa pesantren pada abad ke-16 sangat produktif dan menjadi dinamisator dalam setiap proses sejarah dan perjuangan bangsa. ${ }^{14}$ Harri J. Benda mengakui bahwa sejarah Islam Indonesia adalah sejarah perluasan peradaban santri dan pengaruhnya terhadap kehidupan agama, sosial dan politik Indonesia. ${ }^{15}$ Bahkan menurut Suwito, dunia pesantren dalam lintas sejarah Indonesia, utamanya di Jawa dan Madura, tidak hanya memainkan peran penting dalam transmisi ilmu-ilmu pengetahuan

\footnotetext{
${ }^{9}$ Maulana, adalah sebutan khas India-Pakistan yang diperuntukkan bagi ulama yang berpengetahuan luas atau ulama sufi. Baca Martin van Bruinessen, Kitab Kuning, h. 249.

${ }^{10}$ Marwan Sarijo, Sejarah Pondok Pesantren di Indonesia, (Jakarta: Dhanna Bakti, 1980), h. 24.

${ }^{11}$ Samsul Nizar et. al, Sejarah Sosial dan Dinamika Intelektual Pendidikan Islam di Nusantara, h. 90

${ }^{12}$ Darban, "Kiai dan Politik pada Zaman Kerajaan Islam”, dalam majalah Pesantren, No.2/Vol V, 1998, h. 33-34.

${ }^{13}$ Ahmad Tafsir, Ilmu Pendidikan Islami, (Bandung: Remaja Rosdakarya, 2012), hlm. 290. Lihat juga Sulaiman Ibrahim, Paradigma Baru Ilmu Pendidikan, (Jakarta: Lekas Publishing, 2012), h. 12.

${ }^{14}$ Hasan Muarif Ambary, Menemukan Peradaban: Jejek Arkeologis dan Historis Islam Indonesia, h. 318.

${ }^{15}$ Bahkan ia lebih lanjut mengatakan para penguasa yang baru dinobatkan, selalu bersandar diri kepada para ahli agama, karena hanya merekalah yang dapat mengesahkan pentasbihan mereka. Harry J. Benda, Bulan Sabit dan Matahari Terbit, Islam di Indonesia Pada Masa Pendudukan Jepang, Terj, (Jakarta: Pustaka Jaya, 1985), h. 33.
} 
Islam (tradisional), melainkan juga menjadi mitra penguasa dalam memandu rakyat. Pesantren juga menjadi pusat studi, bahkan juga merupakan basis kaderisasi ulama dan pemimpin politik saat itu. ${ }^{16}$

Abad ke-18 dalam lintasan sejarah dunia pesantren di Indonesia mengalami perubahan. Hal ini diakui Aqib Suminto bahwa abad 18-19 menjadikan lembaga pesantren merupakan perlawanan terhadap kekuatan kolonial Belanda yang dilakukan oleh tokoh-tokoh jebolan pesantren. Cara mereka melawan kolonial adalah tidak memperdulikannya, menutup kerjasama. Bahkan Riwayat pendirian pondok pesantren K.H. Hasyim Asy'ari di Tebuireng Jombang, K.H. As'ad Syamsul Arifin di Asem Bagus Situbondo, K.H. Hamid di Pasuruan, K.H. Kholil Bangkalan Madura, adalah contoh dan tipe pondok yang melakukan reservasi kultural dengan cara menarik diri ke alam pedalaman. ${ }^{17}$ Di samping itu, muncul gerakan perlawanan non akomodatif. Gerakan perlawanan ini umumnya dilakukan tokohtokoh agama, terutama para haji dan organisasi gerakan tarekat. Misalnya, perang Banjar oleh Pangeran Antasari (1859-1862), perang Diponegoro (1825-1830) di Jawa, perang Aceh (1873-1909) hingga perang Paderi (1821-1838) di Sumatera Barat. ${ }^{18}$ Karena itu, pada masa penjajahan Belanda, pondok pesantren memang di samping melaksanakan fungsinya sebagai lembaga pendidikan Islam, juga banyak berperan menjadi pusat-pusat perjuangan bangsa melawan penjajah. Akan tetapi, hal ini dilakukan secara sembunyi-sembunyi, seperti membekali para santri dengan bela diri dan kanuragan.

Respon sistematis pemerintah kolonial terhadap pendidikan pesantren dengan mendirikan sekolah-sekolah umum dengan tujuan ${ }^{19}$ menandingi sistem pendidikan pesantren. Tujuan pendidikan Belanda menurut Abuddin Nata adalah melahirkan manusia yang bermental Budak. Hal ini bisa dilihat dari misi yang dirumuskannya sehingga menghasilkan $^{20}: 1$ ) orang-orang yang tidak mempunyai jiwa merdeka,

\footnotetext{
${ }^{16}$ Suwito \& Muhbib, Jaringan Intelektual Kiai Pesantren, h. 39.

${ }^{17}$ Aqib Suminto, Politik Islam Hindia Belanda, (Jakarta: LP3ES, 1996), h. 202.

${ }^{18}$ M. Annas Mahduri dkk, Pesantren dan Pengembangan Ekonomi Umat: Pesantren al-Ittifaq dalam Perbandingan, h. 27.

${ }^{19}$ Tujuan-tujuan sekolah tersebut antara lain: (1) untuk menghilangkan fanatisme keislaman kaum muslimin dari hati dan pikirannya dan (2) untuk mengimbangi model pendidikan yang dilakukan pesantren. Di samping itu, pemerintahan kolonial menerbitkan Ordonansi Guru Agama, sebuah kebijakan yang dinilai umat Islam sebagai taktik yang tidak hanya sekedar membatasi perkembangan pesantren atau pendidikan Islam saja, tetapi sekaligus menghapus peran penting Islam di Indonesia. Machnun Husein, Pendidikan Islam dalam Lintasan Sejarah, (Yogyakarta: Nur Cahaya, 1983), h. 6.

20 Abuddin Nata, "Pendidikan Islam di Indonesia: Tantangan dan Peluang", dalam Pidato Pengukuhan Guru Besar Tanggal 20 Maret 2004, h. 5.
} 
2) orang-orang yang telah mulai menunjukkan sifat-sifat invidualistis dan kehilangan perasaan kemasyarakatan dan kekeluargaan; 3) orangorang yang mempunyai pengetahuan tanpa disertai kecakapankecakapan praktis dan sikap susila; 4) orang-orang yang pada umumnya bersikap pasif dan tidak memiliki inisiatif serta mudah menyerah pada keadaan. Di samping itu, pemerintahan kolonial juga tidak memberikan bantuan finansial kepada dunia pesantren dengan alasan bahwa kebijakan pemerintah tidak mencampuri urusan agama. Dengan pendirian sekolah-sekolah sekuler tersebut secara massal menyebabkan adanya dikotomi pendidikan di Indonesia. ${ }^{21}$ Akibat dari kebijakan ini, maka timbullah sikap verbalisme dan intelektualisme, hanya mementingkan bahan pelajaran belaka, tidak melatih anak berfikir melalui analisa dan sintesa sehingga mereka tidak menjadi kritis dan tidak kreatif. ${ }^{22}$

Di masa lalu ketika bangsa ini menghadapi penindasan kaum penjajah, pesantren telah memainkan peranan penting berupa menggerakkan, memimpin, dan melakukan perjuangan dalam rangka mengusir kaum penjajah. Seorang pakar sejarah dari Universitas Padjadjaran, Muhammad Mansur Suryanegara, sebagai mana dikutip Tafsir, menyatakan bahwa sulit mencari gerakan melawan penjajah di Indonesia yang bukan digerakkan dan dipimpin oleh orang pesantren. ${ }^{23}$ Bahkan pesantren secara riil memiliki basis kekuatan, pada satu pihak, terletak pada corak dan paham keislaman masyarakat Jawa itu sendiri dan pada pihak lain, basis ekstensial pesantren terletak pada integrasi lembaga ini ke dalam struktur sosial yang ada. ${ }^{24}$ Dengan demikian, pesantren dalam masyarakat Indonesia berfungsi memberikan pelayanan pendidikan dan keagamaan, dan bimbingan sosial, kultural, serta ekonomi bagi masyarakat dilingkungannya. ${ }^{25}$

Perspektif historis, posisi dan peran pesantren di Nusantara dapat dijelaskan secara kronologis sebagai berikut:

a. Abad 12 sampai dengan pertengahan abad 15 pesantren berkembang sebagai sarana sosialisasi Islam dan pendidikan kader ulama dan pemimpin. Pada fase ini, ulama-ulama dari luar Nusantara berperan mengislamkan wilayah Nusantara.

\footnotetext{
${ }^{21}$ Karel A. Steenbrink, Pesantren Madrasah Sekolah, h. 6-7.

${ }^{22}$ Soegarda Poerbakawatja, Pendidikan dalam Alam Indonesia Merdeka, Jakarta, Gunung Agung 1970, Cet I hlm. 242. Yang dikutip oleh Abduddin Nata, "Pendidikan Islam di Indonesia: Tantangan dan Peluang", dalam Pidato Pengukuhan Guru Besar, h. 5.

${ }^{23}$ Ahmad Tafsir, Ilmu Pendidikan dalam Perspektif Islam, h. 192.

${ }^{24}$ Azyumadi Azra, Esei-Esei Intelektual Muslim dan Pendidikan Islam, h. 88. Sulaiman Ibrahim, Pendidikan tentang Manusia dalam Perspektif Al-Qur'an, Jurnal Ilmiah AL-Jauhari, Vol. 2, No. 2, 2017, h. 145-148.

${ }^{25}$ Azyumadi Azra, Pendidikan Islam; Tradisi dan Modernisasi, h. 108.
} 
b. Akhir abad 15 sampai pertengahan abad 16, pesantren menjadi salah satu pusat pendidikan dan penyiapan kader elite birokrasi kerajaan dan ulama lokal sudah menjadi penyebar Islam di Nusantara.

c. Pertengahan abad 16 sampai abad 17 pesantren menjadi alat legitimasi kekuasaan.

d. Pertengahan abad 17 sampai akhir abad 17 mulai muncul jarak atau rivalitas antara pesantren dengan elit birokrasi, khususnya ketika pusat Islam bergeser ke pedalaman (Mataram Islam).

e. Akhir abad 17 sampai akhir abad 18 peranan pesantren sebagai acua legitimasi merupakan alat salah satu elite birokrasi kerajaan.

f. Akhir abad 18 fenomena sejarah menunjukkan adanya pesantren dihancurkan (Kajoran, Giri, Sumenep, dan lain-lain)

g. Akhir abad 18 hingga 19 pesantren "menjauhi" pusat kekuasaan yang banyak menjadi perpanjangan tengan kekuasaan kolonial, sementara pesantren kembali menjadi sandaran aspirasi umat. ${ }^{26}$

Ambary tampaknya belum menganalisis lebih jauh mengenai dinamika pesantren di abad ke-20. Karena itu, patut diduga kuat bahwa pesantren di abad tersebut mengalami perubahan yang sangat signifikansi. ${ }^{27}$ Di mana pada pertengahan abad ke-20, lembaga pendidikan Islam tradisional ini banyak melakukan ekspansi dari wilayah pedesaan ke berbagai wilayah perkotaan. ${ }^{28}$ Pesantren tidak hanya menjadi pusat dan lembaga pendidikan Islam tradisional dan lembaga penyiaran/dakwa Islam, melainkan juga merupakan lembaga sosial, yang memberikan warna khas bagi perkembangan masyarakat sekitarnya dan masyarakat daerah asal santri. ${ }^{29}$ Dengan kata lain, lembaga pendidikan pesantren telah berhasil seperti yang diistilahkan Mastuhu perang nilai, antara pesantren dengan masyarakat sekitarnya, dan diakhiri dengan kemenangan pada pihak pesantren, sehingga pesantren dapat diterima hidup di dalam masyarakat dan menjadi panutan di bidang moral. ${ }^{30}$

\footnotetext{
${ }^{26}$ Suwito, Muhbib, Jaringan Intelektual Kiai Pesantren di Jawa-Madura Abad XX, 34-35. Yang dikutip dari Hasan Muarif Ambary, Menemukan Peradaban: Jejek Arkeologis dan Historis Islam, hlm. 314. Nurhamida, Internalisasi Nilai-Nilai Pendidikan Kewirausahaan dalam Kurikulum di SMK Salafiyah Syafi'iyah, Jurnal Ilmiah AL-Jauhari, (Volume 3 No 1, Juni 2018), h. 19

${ }^{27}$ Suwito, Muhbib, Jaringan Intelektual Kyai Pesantren di Jawa-Madura, h. 35 .

${ }^{28}$ Ahmad Syafi'ie Noor, Orientasi Pengembangan Pendidikan Pesantren,

h. 3 .

${ }^{29}$ Andi M. Ramli, Gambaran Singkat tentang Pendidikan di Pesantren, dalam Buletin Bina Pesantren, (Depag RI, Juli 1999), h. 6.

${ }^{30}$ Mastuhu, Dinamika Sistem Pendidikan Pesantren, h. 20. 
Menurut Atho Mudzar dunia pendidikan pesantren memperhatikan perubahan sosial yang terjadi dengan mengagendakan beberapa hal: ${ }^{31}$ Pertama, pesantren memosisikan sebagai lembaga pendidikan kegamaan (keislaman) yang tetap menjadi sentral tafaqquh $f i$ al-dien yang berfungsi memelihara, mengembangkan dan memanfaatkan ilmu-ilmu keislaman. Strategi pembelajarannya, pesantren tidak perlu anti-iptek modern, tetapi menggunakannya untuk mencapai efektifitas belajar.

Kedua, pesantren dapat mengembangkan ilmu-ilmu umum semaksimal mungkin dalam upaya beradaptasi dengan kemajuan iptek yang berkembang dan dibutuhkan dimasyarakat. Dalam konteks ini pendidikan pesantren dapat menjalankan fungsi islamisasi ilmu (Islamization of sciences). Ketiga, sebagai lembaga peradaban, pesantren sudah saatnya memperhatikan tuntutan ideologi global yang berkembang. Di samping menjalankan fungsi pemeliharaan atau pelestarian nilai-nilai local (localities) yang baik, positif dan bermanfaat bagi pesantren juga sudah saatnya mengadaptasinya selama tidak menghancurkan lokalitas.

Keempat, sebagai agen perubahan sosial-ekonomi, yang notabene merupakan lemabga pendidikan dari dan untuk masyarakat, atau lembaga berbasis masyarakat, maka pesantren dituntut berpartisipasi aktif dalam perekonomian masyarakat sekitarnya. Kelima, dalam aspek kurikulum pesantren mengembankan keunggulan sesuai visi, misi, dan tuntutan perkembangan kebutuhan masyarakat, dengan memanfaatkan kemajuan iptek yang berkembang.

\section{Gambaran Singkat Pesantren Ummushabri Kendari}

Pesantren Ummusshabri merupakan lembaga yang berafiliasi atau berada di bawah naungan organisasi keagamaan, yakni GUPPI (Gabungan Usaha Perbaikan Pendidikan Islam) Provinsi Sulawesi Tenggara. Pesantren Ummusshabri didirikan pada tahun 1971 dengan prakarsa para pendiri yang terdiri dari: Mayjen (purn) H. Eddy Sabara (alm), H. Muhtarum, S.H., K.H. Baedhawi (alm), Drs. H. Abdullah Silondae, H.A. Madjid Yoenoes (alm), H.A. Karim Aburaera, S.H., Drs. H. Djalante P., Drs. A. Hairul Azibin, P. Rafiuddin Amir (alm), Nurdin Dg. Magassing, Drs. H. Sappena Mustarim, H. Abd Rahim Munier, dan Ir. H. Muh. Saleh. Mereka inilah yang telah bekerja keras selama kurang lebih dua tahun sehingga Pesantren Ummusshabri dapat diresmikan penggunaannya pada tanggal 9 Januari 1974 oleh Menteri Agama (waktu itu Prof. Dr. H. Mukti Ali) atas nama Presiden Republik Indonesia.

\footnotetext{
${ }^{31}$ Atho Mudzhar, "Pesantren Transformatif: Respon Pesantren terhadap Perubahan Sosial”, h. 13-14.
} 
Tanpa bermaksud mengabaikan peranan kesemua pendiri tersebut, di sini dapat dikatakan, bahwa di antara para perintis dan pendiri Pesantren Ummusshabri tersebut, KH. Baedhawi ${ }^{32}$ adalah yang sangat banyak jasanya dalam pembinaan dan pengembangan Pesantren Ummusshabri. KH. Baedhawi adalah pimpinan pertama Pesantren Ummusshabri yang ikut terjun langsung dalam perintisan, pembangunan, pembinaan, dan pengembangan pesantren. Ia juga secara langsung mendidik santri sejak awal berdirinya pesantren. Itulah sebabnya pada acara-acara tertentu, terutama acara ulang tahun Pesantren Ummusshabri, nama KH. Baedhawi tidak pernah alpa disebut, seperti pada saat ulang tahun Pesantren Ummusshabri ke-34 tahun 2008. Tujuan yang ingin dicapai dari upaya pembangunan pesantren modern tersebut adalah untuk mendidik kader-kader muslim warga negara Indonesia yang berdasarkan Pancasila dan Undang Undang Dasar 1945 agar memiliki sifat-sifat, seperti: beriman, cakap terampil, takwa penuh dedikasi dan insya Allah akan berguna untuk kemajuan dunia dan akhirat. ${ }^{33}$ Beberapa faktor yang melatarbelakangi sehingga GUPPI berupaya keras untuk mewujudkan pendirian pesantren di Sulawesi Tenggara, di antaranya adalah: pertama, faktor psikologis, yakni untuk mengimbangi tuntutan kemajuan yang terus berpacu di berbagai bidang, yang ilmu pengetahuan dan teknologi sebagai motor penggeraknya. Kedua, sebagai organisasi yang bergerak di bidang pendidikan Islam, GUPPI merasa berkewajiban untuk mengabdikan dirinya bagi kemajuan umat Islam khususnya di Sulawesi Tenggara. Ketiga, bahwa pondok pesantren merupakan lembaga pendidikan yang sangat relevan dengan kondisi masyarakat dan sekaligus sebagai lembaga pendidikan yang dibutuhkan dalam mendidik anak-anak muslim yang memiliki kepribadian muslim yang utuh.

${ }^{32}$ KH. Baedhawi lahir di Palopo (Sulawesi Selatan) pada tanggal 25 Agustus 1925. Pendidikannya dimulai di Standard School kemudian dilanjutkannya di Madrasah Aliyah Pare-Pare (Sulawesi Selatan) dan di Muallimin Watangsoppeng (Sulawesi Selatan). Di antara gurunya adalah KH. As'ad, KH. Husain, dan KH. Ahmad Bone. Ia juga pernah mengikuti Takhassus Muallimin di Madinah. Di Madinah, ia belajar kepada gurunya, Mufti Syekh Mahmud 'Abd al-Jawab. Di antara karya KH. Baedhawi adalah: Pengantar Ilmu Tafsir (1973), Meninjau Secara Singkat Apa yang Dimaksud dengan Amir-Imamah-Jamaah dan Bid'ah (1976), dan Tuntunan Syarat Shahnya Shalat Jum'at, (1982). Pada waktu memimpin Pesantren Ummusshabri, KH. Baedhawi menjabat sebagai Kepala Kantor Perwakilan Departemen Agama Sulawesi Tenggara. Lihat Badan Penelitian dan Pengembangan Agama Depag RI, "Penyusunan Bibliografi Beranotasi tentang Karya Ulama di Sulawesi Tenggara, Tengah \& Utara", Laporan Penelitian (Ujungpandang: Balai Penelitian Lektur Keagamaan Ujungpandang, 1982/1983), h. 42-45.

${ }^{33}$ Muhtarum, Ketua Umum Gabungan Usaha Perbaikan Pendidikan Islam (GUPPI) Konsulat Sulawesi Tenggara, Sambutan, Kendari, 20 Oktober 2011. 
Selama sepuluh tahun (dari tahun 1974 sampai tahun 1984), Pesantren Ummusshabri tetap menjadi idola masyarakat Sulawesi Tenggara. Ketertarikan masyarakat pada pondok pesantren ini bukan hanya karena bangunannya yang tergolong mewah menurut ukuran Kota Kendari saat itu, atau karena biaya pendidikannya ditanggulangi oleh Pemerintah Daerah, tetapi lebih dari itu didorong oleh naluri keyakinan tentang kharisma Pesantren Ummusshabri sebagai kampus pendidikan Islam tempat mencetak kader manusia muslim yang tangguh sampai ke puncak kesabaran sesuai dengan makna dari nama Pesantren Ummusshabri. ${ }^{34}$

Pada awal berdirinya, Pesantren Ummusshabri yang menyelenggarakan pendidikan non formal juga mengelola pendidikan formal tingkat Madrasah Aliyah sampai tahun 1986. Melihat kebutuhan dan tuntutan masyarakat terhadap Pesantren Ummusshabri semakin meningkat, pada tahun 1986 dibuka Madrasah Tsanawiyah (MTs) dan Madrasah Diniyah tingkat Awaliyah dan Wustha. Di samping pendidikan formal tersebut, Pesantren Ummusshabri juga menyelenggarakan pendidikan keterampilan, seperti pertukangan, perkebunan, pertanian, peternakan, perikanan, bahkan usaha koperasi, warung serba ada (waserda), dan poliklinik/rumah bersalin. Akan

34"Menengok Pesantren Ummusshabri Kendari", Harian Pelita, 10 Oktober 1984. Nama Pesantren Ummusshabri diberikan oleh KH. Baedhawi (pimpinan pertama) yang secara harfiah berarti ibunya kesabaran, tetapi makna yang dimaksudkan adalah puncak kesabaran. Ada anggapan bahwa nama tersebut diberikan karena sesuai dengan nama pimpinan tertinggi Sulawesi Tenggara saat itu yang sekaligus sebagai salah seorang pendiri pesantren, yakni Edi Sabara. Namun, hal ini diakui hanya kebetulan saja. Hasil telewawancara dengan H. Baso Suamir, Pimpinan Pesantren Ummusshabri Kendari, tanggal 30 Juli 2008. H. Baso Suamir lahir di Bajo, Palopo, Sulawesi Selatan tanggal 31 Desember 1943. Tamat SR di Bajo tahun 1955, PGA 4 tahun di Palopo tahun 1964, PGA 6 tahun di Palopo tahun 1965, selesai Sarjana Muda Jurusan Dakwah Fakultas Ushuluddin IAIN Alauddin Ujungpandang tahun 1971. Pendidikan terakhirnya sebagai Sarjana Lengkap Administrasi Negara di Universitas Terbuka Kendari tahun 1990. Pengalamannya dalam bidang organisasi antara lain: Ketua PII Cabang Palopo tahun 1964, Wakil Ketua PII Cabang Makassar tahun 1965, Ketua PII Cabang Makassar tahun 1967 dan Sekretaris Umum PW PII Sulawesi Selatan tahun 1971-1973. Ia juga pernah menjadi Wakil Sekretaris PC Muhammadiyah Cabang Ujung Tanah Makassar. Ia menetap di Kendari sebagai PNS di lingkungan Kanwil Depag Provinsi Sulawesi Tenggara. Ia telah mengabdi di Pesantren Ummusshabri Kendari sejak 1973 dan sebagai Pimpinan Pesantren tersebut sejak tahun 1986 hingga sekarang. Di samping itu, ia juga sebagai Ketua Majelis Tabligh dan Dakwah Khusus PW Muhammadiyah Sulawesi Tenggara tahun 2001-2005, Ketua Majelis Tarjih PW Muhammadiyah Provinsi Sulawesi Tenggara tahun 2006 hingga sekarang, Sekretaris Umum Bakomubin Provinsi Sulawesi Tenggara hingga sekarang dan Ketua Kerukunan Keluarga Luwu hingga sekarang. Selain itu, ia juga aktif di partai politik dan sekarang menjadi anggota (Pengganti Antar Waktu) DPRD Propinsi Sulawesi Tenggara dari Partai Bulan Bintang (PBB). 
tetapi, sejak tahun 2001, beberapa program keterampilan, termasuk layanan poliklinik/rumah bersalin tersebut tidak dijalankan lagi, sehingga yang ada sekarang hanya waserda (warung serba ada), usaha aneka minuman sari buah, produksi nata de coco, dan produksi minyak goreng. Sejalan dengan laju perkembangan pembangunan kota yang semakin cepat dewasa ini, Pesantren Ummusshabri tidak lagi menjadi idola masyarakat seperti pada awal berdirinya. Dari segi sarana dan prasarana pendidikan, Pesantren Ummusshabri seolah-olah telah ditelan oleh bangunan-bangunan megah yang berdiri di sekeliling kampus pesantren. Begitu juga dengan hadirnya lembagalembaga pendidikan pesantren lainnya, terutama dengan didirikannya Pondok Modern Gontor VII (putra) di Pudahoa dan Pondok Modern Gontor IV (putri) di Konda (Kabupaten Konawe Selatan). Sampai usianya yang ke-34, Pesantren Ummusshabri tampaknya hanya mengalami kemajuan terutama di bidang pembangunan pisik dan pendidikan formal madrasah, tetapi pendidikan nonformal khususnya kepesantrenan mengalami kemunduran. Kemunduran itu terjadi antara lain disebabkan oleh kurang berfungsinya manajemen/kepemimpinan pesantren dengan baik. ${ }^{35}$ Menyadari ketertinggalan selama puluhan tahun tersebut, Pesantren Ummusshabri sekarang tengah mengadakan pembenahan diri yang dimulai dari manajemen kepemimpinan dan organisasi. Mulai tahun pelajaran 2008/2009, Pesantren Ummusshabri memperbarui sistem kepengurusannya dengan menerapkan model direksi, sehingga bagian-bagian penting pelaksana kegiatan dalam pesantren dipimpin oleh seorang direktur sesuai bidang kegiatan pesantren ke depan adalah "Menjadikan Pesantren Ummusshabri sebagai pusat kegiatan Islam Kota Kendari”.

Adapun misi Pesantren Ummusshabri adalah: 1) Penyelenggaraan pendidikan formal, nonformal, dan keterampilan; 2) pembinaan anak yatim, fakir miskin (du'afā), dan mu'allaf; 3) pemberdayaan ekonomi umat; 4) pelayanan sosial dan kemasyarakatan; dan 5) penyelenggaraan dakwah Islam. ${ }^{36}$ Untuk mewujudkan visi dan misi tersebut, pengelola pesantren telah memasukkan dua bidang kegiatan dalam pesantren yakni direktorat amal sosial yang menangani semua kegiatan pelayanan sosial

\footnotetext{
${ }^{35}$ Hasil wawancara dengan Sunayat, Pengasuh/Pengawas Asrama Santri I Pesantren Ummusshabri Kendari, tanggal 24 Juni 2013 di Kantor Pesantren Ummusshabri Kendari. Sunayat lahir di Landono, 10 April 1982. Sunayat menamatkan pendidikannya pada SDN Landono tahun 1995, dan MTs Tridana tahun 1998. Setelah tamat dari MAS Pesantren Ummusshabri tahun 2001, ia melanjutkan pendidikan di Jurusan Tarbiyah STAIN Kendari dan sampai sekarang masih berstatus sebagai mahasiswa. Di Pesantren Ummusshabri, di samping sebagai pengasuh/pengawas asrama, ia juga menjabat sebagai Kepala Bagian Personalia.

${ }^{36}$ Profil Pesantren Ummusshabri Kendari Tahun 2010/2012.
} 
khususnya kepada umat Islam dan direktorat amal usaha yang menangani pelayanan umat di bidang ekonomi khususnya produksi dan pemasaran kebutuhan pokok masyarakat. Sebagai motivasi dalam mewujudkan visi dan misi pesantren tersebut, Pesantren Ummusshabri membuat semboyan yang dipampang di bagian depan kampus pesantren, yakni "Menggapai hari ini lebih baik dari hari kemarin dan hari esok yang lebih baik dari hari ini".

\section{Perspektif Historis Oreintasi Perubahan Kurikulum}

Penelitian ini berfokus pada masalah perubahan kurikulum pendidikan pada pesantren Ummusshabri Kendari. Namun demikian, perspektif historis perubahan kurikulum pesantren pada awal abad ke20 beberapa Muslim modernis yang ke Indonesia dari Timur Tengah melakukan modifikasi terhadap model pendidikan sekuler Belanda. ${ }^{37}$ Mereka tidak menolak sepenuhnya yang datang dari Belanda, tetapi mengadaptasi sebagian yang dianggap baik seperti sistem madrasah yang berbeda dari lembaga pendidikan tradisional sebelumnya, yaitu surau. Materi ajar yang semula terpusat Al-Qur'an, hadis, tafsir, kitab kuning, serta nahwu dan sharaf, ditambah kurikulum umum seperti aljabar, dan ilmu bumi. ${ }^{38}$

Dalam konteks inilah muncul dua bentuk lembaga pendidikan modern Islam. Pertama, sekolah-sekolah umum model Belanda diberi muatan pengajaran Islam. Kedua, madrasah-madrasah modern yang secara terbatas mengadopsi substansi dan metodologi pendidikan modern Belanda. Dalam bentuk pertama dapat disebut sekolah Adabiyah yang dirikan Abdullah Ahamad di Padang pada tahun 1909 dan sekolah-sekolah Muhammdiyah. Sedangkan bentuk kedua ditemukan sekolah Diniyah Zainuddin Labay el-Yunusia atau Sumatera Thawalib, madrasah yang didirikan al-Jam'iyatul alKhairiyah, dan madrasah yang didirikan organisasi al-Irsyad. ${ }^{39}$ Demikian halnya, sistem pendidikan Islam tradisional di Jawa yakni pesantren telah memberikan respon terhadap kemunculan dan ekspansi sistem pendidikan modern Islam ini, dengan memimjam

\footnotetext{
${ }^{37}$ Mundzier Suparta, Perubahan Orientasi Pondok Pesantren Salafiyah: Terhadap Perilaku Keagamaan Masyarakat, (Jakarta, Asta Buana Sejahtera, 2009), h. 69.

${ }^{38}$ Mundzier Suparta, Perubahan Orientasi Pondok Pesantren Salafiyah, h. 69. Abdullah Diu, Pemikiran M. Amin Abdullah tentang Pendidikan Islam dalam Pendekatan Integrasi-Interkoneksi. Jurnal Ilmiah AL-Jauhari: Jurnal Studi Islam Dan Interdisipliner, 3(1), 2018, 1-15.

${ }^{39}$ Delier Noer, Gerakan Modern Islam di Indonesia 1900-1942, (Jakarta, LP3ES, 1998), h. 38-104.
} 
istilah A. Karel Steenbrink, monolak sambil mengikuti, ${ }^{40}$ pada saat yang sama mengikuti langka kaum reformis untuk bisa tetap bertahan. Karena itulah, pesantren melakukan sejumlah teori akomodasi dan penyesuaian yang meraka anggap tidak hanya akan mendukung kontiniutas pesantren, tetapi juga bermanfaat bagi para santri, seperti sistem penjenjangan, kurikulum yang lebih jelas, dan sistem klasikal.

Pesantren ${ }^{41}$ Tebuireng, misalnya pada tahun 1916 mendirikan sebuah madrasah salafiyah yang tidak hanya mengadopsi sistem pendidikan modern, tetapi juga memasukkan beberapa pelajaran umum seperti berhitung, bahasa Melayu, ilmu bumi, dan menulis dengan huruf Latin kedalam kurikulumnya. ${ }^{42}$ Selajutnya pada tahun 1926 berdiri Pondok Modern Gontor. Pondok ini selain memasukkan sejumlah mata pelajaran umum ke dalam kurikulum, juga mendorong para santri untuk mempelajari bahasa Inggris, selain bahasa Arab, dan melaksanakan sejumlah kegiatan ekstra-kurikuler seperti olah raga dan kesenian. Bahkan secara kelembagaan, Gontor telah melakukan terobosan dengan mewakafkan seluru asetnya kepada Badan Wakaf agar ketika para pendiri meninggal dunia, pesantren tidak diwarisi oleh keluarga seperti terjasi di banyak pesantren, tetapi Badan Wakaf yang meneruskan estafet kepemimpinan pondok pesantren. ${ }^{43}$

Deskripsi singkat di atas sedikit banyak menjelaskan bagaimana upaya pesantren merespon modernisasi dan perubahan di sekelilingnya. Dalam menghadapi semua semua perubahan dan modernisasi, para ekponen pesantren tidak tergesa-gesa mentransformasikan kelembagaan pesantren menjadi lembaga pendidikan modern Islam sepenuhnya tetapi sebaliknya cenderung mempertahankan kebijakan dan hati-hati (cautius policy), mereka menerima pembaharuan pendidikan Islam dalam skala terbatas; sebatas mampu menjamin pesantren bisa tetap mempunyai eksistensi. $^{44}$

\footnotetext{
${ }^{40}$ Karel A. Stennbrink, Pesantren, Madrasah, Sekolah; Pendidikan Islam dalam Kurun Modern, (Jakarta, LP3ES, 1998), h. 38-104.

${ }^{41}$ Menurut suatu pendapat, pesantren yang pertama kali melakukan pembaharuan adalah Mambaul Ulum di Surakarta. Pesantren ini didirikan oleh Susuhunan Pakubuwono tahun 1906, dengan memasukkan mata pelajaran umum dalam kurikulum pendidikannya, seperti pelajaran membaca dan menulis huruf latin, aljabar dan berhitung. Lihat Andre Fellend, Lesmana, NU Vis-a Vis Negeri Pencari Isi, Bentuk dan Makna, (Yogyakarta, LKIS, 1999), h. 8-9.

${ }^{42}$ Zamakhsyari Dhofier, Tradisi Pesantren; Studi Tentang Pandangan Kyai, h. $100-126$.

${ }^{43}$ Untuk kasus Gontor, lihat Abdullah Syukri Zarkasyi, Gontor dan Pembaharuan Pendidikan Pesantren, (Jakarta, Rajawali, 2005), h. 45-55

${ }^{44}$ Azyumardi Azra, Pendidikan Islam; Tradisi dan Modernisasi Menuju Milenium Baru, (Jakarta, Logos Wacana Ilmu, 2000), h. 101.
} 
Orientasi Perubahan Kurikulum Pesantren Ummushabri Kendari

Secara terminologis, term kurikulum memiliki pengertian yang bervariasi, tergantung pada latar belakang perumusnya. Undangundang R.I. Nomor 20 Tahun 2003 tentang Sistem Pendidikan Nasional mendefinisikan pengertian kurikulum sebagai seperangkat rencara dan pengaturan mengenai tujuan, isi, dan bahan pelajaran serta cara yang digunakan sebagai pedoman penyelenggaraan kegiatan pembelajaran untuk mencapai tujuan pendidikan tertentu." ${ }^{45}$

Pengertian ini bila diimplementasikan haruslah mempertimbangkan asas-asas kurikulum yang lazim berupa asas relevansi filosofis, psikologis, dan sosiologis. Asas relevansi filosofis dibutuhkan karena penyelenggaraan pendidikan di wilayah Indonesia haruslah mempertimbangkan ideologi atau falsafah negara yang menjadi acuan dasar dalam bermasyarakat, berbangsa, dan bernegara, termasuk dalam menentukan arah pendidikan. Sedangkan asas psikologis dibutuhkan karena keberadaan anak tidak boleh hanya diposisikan sebagai obyek belaka melainkan harus pula dipandang sebagai subyek pendidikan itu sendiri. Dengan begitu kurikulum haruslah mempertimbangkan minat dan perkembangan anak secara sungguh-sungguh. Selanjutnya asas sosiologis diperlukan karena asas ini menekankan bahwa anak tidak hidup sendiri, ia merupakan bagian dari masyarakatnya. Di situlah ia mesti memenuhi tugas tugasnya yang harus dilakukannya dengan penuh tanggung jawab, baik sebagai anak, maupun sebagai orang dewasa kelak. ${ }^{46}$ Khususnya dalam konteks pesantren pembaharuan berarti mengadakan perubahan dari sistem pembelajaran tradisional yang mono leader dengan sistem belajar halaqah ${ }^{47}$ ke sistem belajar klasikal.

Penerapan kurikulum di Pesantren Ummushabri, secara ideal, disesuaikan dengan tujuan pesantren itu sendiri dengan tetap menekankan asas relevansi filosofis dari negara Republik Indonesia, yaitu: membantu pemerintah mencerdaskan kehidupan bangsa, membangun manusia Indonesia seutuhnya yang berakhlak mulia, berbadan sehat, dan berpengetahuan luas, serta mendidik santri menjadi calon ulama-intelek ". Itulah sebabnya, ketika pertama kali dioperasikan, pesantren ini menerapkan kurikulum dengan komposisi $50 \%$ umum dan $50 \%$ agama. Hal ini terungkap dalam wawancara

\footnotetext{
${ }^{45}$ Undang-undang Rebublik Indonesia No. 20 Tahun 2003 tentang Sistem Pendidikan Nasional (SISDIKNAS), (Bandung: Citra Umbara, 2003), h. 5.

${ }^{46}$ S. Nasution, Asas-asas Kurikulum, edisi kedua, (Jakarta: Bumi Aksara, 1995), h.10-13.

${ }^{47}$ halaqah berarti lingkaran yang di dalam sistem pendidikan adalah kumpulan orangorang yang duduk berbentuk lingkaran. Lihat A.W. Munawwir, Kamus al-Munawwir, h. 314. 40.
} 
dengan direktur Ketiga, Supriyanto : Sebagai direktur pengembangan Pesantren, telah untuk menyusun kurikulum bagi lembaga pendidikan ini. Waktu itu, kurikulum disusun dengan komposisi $50 \%$ umum dan $50 \%$ agama.

Komposisi kurikulum ini berlaku bagi kurikulum formal, tetapi sebagai lembaga pesantren, kurikulum tersebut belum dianggap mewakili dimensi pesantren, sehingga ditambah lagi dengan kurikulum internal pesantren. ${ }^{48}$ Komposisi kurikulum $50 \%$ umum dan $50 \%$ agama berlaku untuk kurikulum formal91. Komposisi tersebut dilatarbelakangi keadaan waktu itu, yaitu adanya keinginan untuk mengafiliasikan lembaga pendidikan ini kepada dua departemen sekaligus, Departemen Agama dan Departemen Pendidikan dan Kebudayaan (sekarang Departemen Pendidikan Nasional). Akan tetapi, baik kurikulum Depag maupun lembaga pendidikan ini untuk mewujudkan tujuannya menciptakan calon ulama intelek.

Untuk itu, pengelola Pesantren Ummushabri merancang kurikulum internal pesantren yang dimaksudkan menjadi kekuatan atau ciri khas lembaga pendidikan ini. Begitu pentingnya eksistensi kurikulum bagi sebuah lembaga pendidikan, menyebabkan direktur pertama Pesantren Ummushabri memusatkan perhatiannya pada usaha penyusunan kurikulum yang komprehensif dengan merujuk pada kurikulum sejumlah pesantren di pulau Jawa. Yang pertama-tama saya susun adalah kurikulum pesantren. Kurikulum Pondok Modern Gontor kami pelajari. Begitu pula kurikulum Pesantren Darul Falah Bogor dan Pesantren Bangil. Akhirnya kurikulum Pesantren Ummushabri dirumuskan menjadi empat komponen utama, yaitu: pengetahuan agama, pengetahuan umum, bahasa, dan keterampilan. Persentase pengetahuan umum dan agama dibuat seimbang (50:50\%), sedangkan bahasa yang diutamakan adalah bahasa Arab, Inggris, dan Indonesia.

Jadi, kurikulum pesantren ini oleh pengelolanya dipetakan menjadi komponen pengetahuan agama untuk pembentukan ulama, pengetahuan umum untuk pembentukan intelek, bahasa untuk kepentingan akses ke berbagai pengetahuan, dan keterampilan untuk bekal praktis para santri ketika mereka sudah menjadi alumni dan menjalani kehidupan di masyarakat.

Secara umum, perkembangan kurikulum Pesantren Ummusshabri sebagaimana tampak pada tabel 1. Perkembangan Kurikulum Pesantren dari Periode ke Periode. ${ }^{49}$

\footnotetext{
${ }^{48}$ Wawancara dengan Supriyanto Kepala Bagian Pengembangan Pesantren Ummushabri Kendari, Tanggal 23- September 2013

49 Zainal Mustaming, Direktur Pesantren periode 1998-sekarang, Wawancara, Kendari, 9 Nopember 2013. 


\begin{tabular}{|c|c|c|c|}
\hline Periode & $\begin{array}{c}\text { Sumber } \\
\text { Kurikulum }\end{array}$ & Sifat & Keterangan \\
\hline \multirow[t]{3}{*}{ 1986-1994 } & $\begin{array}{l}\text { Departemen } \\
\text { Agama }\end{array}$ & Formal & $\begin{array}{l}\text { Kurikulum Depag } \\
\text { Diberlakukan } \\
\text { dengan modifikasi }\end{array}$ \\
\hline & $\begin{array}{l}\text { Dep. Pendidikan } \\
\text { dan Kebudayaan }\end{array}$ & Formal & $\begin{array}{l}\text { Kurikulum } \\
\text { Depdikbud } \\
\text { diberlakukan } \\
\text { dengan modifikasi }\end{array}$ \\
\hline & $\begin{array}{l}\text { Pengelola } \\
\text { Pesantren }\end{array}$ & Nonformal & $\begin{array}{l}\text { Kurikulum } \\
\text { kepesantrenan } \\
\text { diajarkan di luar } \\
\text { kelas (nonklasikal) }\end{array}$ \\
\hline \multirow[t]{2}{*}{ 1996-Sekarang } & $\begin{array}{l}\text { Dep. Pendidikan } \\
\text { dan Kebudayaan }\end{array}$ & Formal & $\begin{array}{l}\text { Kurikulum } \\
\text { Depdikbud } \\
\text { diberlakukan tanpa } \\
\text { kurikulum Depag, } \\
\text { tetapi ditambah } \\
\text { muatan lokal }\end{array}$ \\
\hline & $\begin{array}{l}\text { Pengelola } \\
\text { Pesantren }\end{array}$ & Nonformal & $\begin{array}{l}\text { Kurikulum } \\
\text { kepesantrenan } \\
\text { diajarkan di luar } \\
\text { kelas (nonklasikal) }\end{array}$ \\
\hline
\end{tabular}

Data di atas, menunjukkan adanya pembaruan kurikulum dari periode ke periode. Pembaharuan tersebut berupa pembaharuan sumber kurikulum dan pembaruan sifat kurikulum itu sendiri. Pembaruan sumber kurikulum dilakukan dengan jalan efisiensi dari tiga sumber menjadi dua sumber saja. Semula kurikulum bersumber dari Departemen Agama, Departemen Pendidikan dan Kebudayaan, dan pengelola pesantren. ${ }^{50}$ Akan tetapi, penerapan tiga kurikulum sekaligus, walaupun telah melalui serangkaian modifikasi,tampaknya tidak dimungkinkan oleh aturan yang dikeluarkan pemerintah pada waktu itu. Oleh karena itu, pengelola pesantren hanya mengakomodasi kurikulum Depdikbud dan melepaskan kurikulum Depag. Lalu, untuk menjaga ciri khas pesantren sebagai lembaga pendidikan Islam, maka dirancanglah kurikulum yang diberi nama kurikulum kepesantrenan.

Di sini, sifat kurikulum kepesantrenan ditingkatkan statusnya dari sekedar kurikulum nonformal menjadi kurikulum formal dan nonformal. Pembaharuan berupa peningkatan status kurikulum

${ }^{50}$ Kurikulum Departemen Agama dan Departemen Pendidikan dan Kebudayaan pernah diberlakukan secara bersamaan di Pesantren Ummushabri. Pemberlakuan itu dimaksudkan untuk mengakomodasi kebutuhan santri terhadap dua jenis ijazah, yaitu: ijazah MTs, MA,. Ketika itu diasumsikan bahwa dengan memiliki dua jenis ijazah akan memudahkan para alumni untuk memasuki atau melanjutkan ke berbagai jenjang pendidikan yang lebih tinggi. Akan tetapi, keadaan seperti itu telah menyebabkan ketidakakuratan data, baik yang diterima 
kepesantrenan yang sebelumnya hanya nonformal saja, menjadi formal dan nonformal membawa dua konsekuensi, yaitu: pertama, untuk kelompok mata pelajaran yang masuk kurikulum kepesantrenan formal diajarkan secara klasikal di dalam kelas, sama statusnya seperti kelompok mata pelajaran yang bersumber dari kurikulum Depdikbud; dan kedua, untuk kelompok mata pelajaran yang masuk kurikulum kepesantrenan nonformal diajarkan tidak secara klasikal, tetapi mengambil jam di luar kurikulum formal. Walaupun tidak lagi menggunakan kurikulum Departemen Agama secara formal sejak tahun 1994, tetapi sampai dengan tahun 1999 komposisi kurikulum Pesantren Ummusshabri masih belum banyak berubah. Artinya, kurikulum Departemen Agama yang diterapkan selama ini-sedikit banyaknya masih tetap berlaku, tetapi tidak lagi diujikan dalam rangka mendapatkan ijazah MTs dan Madrasah Aliyah. Keadaan ini disadari benar oleh pengelola Pesantren Ummushabri sebagai kurikulum yang mengambang. Namun demikian faktanya, kurikulum Departemen Agama dengan sistem madrasah masih mendominasi. Hal ini telihat sumber kurikulum 2000/2011 yang dipakai:

\begin{tabular}{|c|c|c|c|}
\hline $\begin{array}{l}\text { Pendidikan Agama } \\
\text { Kurikulum } \\
\text { Kementerian Agama }\end{array}$ & $\begin{array}{l}\text { Pendidikan Umum } \\
\text { Kurikulum } \\
\text { Departemen } \\
\text { Pendidikan dan } \\
\text { Kebudayaan }\end{array}$ & Muatan Lokal & $\begin{array}{l}\text { Kurikulum } \\
\text { Kepesantrenan }\end{array}$ \\
\hline $\begin{array}{l}\text { 1. Alquran/Tajwid } \\
\text { 2. Tafsir/Hadis } \\
\text { 3. Akidah/Akhlak } \\
\text { 4. Fikih } \\
\text { 5. Usul Fikih } \\
\text { 6. Sejarah Islam } \\
\text { 7. Bahasa Arab }\end{array}$ & $\begin{array}{ll}\text { 1. } & \text { PPKn } \\
\text { 2. } & \text { Bhs \&Sastra } \\
\text { Indo } \\
\text { 3. } \\
\text { 4. } \text { Fatematika } \\
\text { 5. } & \text { Biologi } \\
\text { 6. } & \text { Kimia } \\
\text { 7. } & \text { Geografi } \\
\text { 8. } & \text { Ekonomi } \\
\text { 9. } & \text { Sej. Nasional/ } \\
\text { 10. Umum } \\
\text { 10. } \text { Bhs. Inggris } \\
\text { 11. KTK/Seni } \\
\text { 12. Penjaskes } \\
\text { 13. Sosiologi } \\
\text { 14. Antropologi } \\
\text { 15. } & \text { Tata Negara }\end{array}$ & $\begin{array}{l}\text { 1. Komputer } \\
\text { 2. Elektro } \\
\text { 3. Bahasa } \\
\text { Lokal }\end{array}$ & $\begin{array}{l}\text { 1. Baca al-Qur'an } \\
\text { dan Tajwid } \\
\text { 2. Latihan } \\
\text { dakwah }\end{array}$ \\
\hline
\end{tabular}

Jika kurikulum formal bersumber dari pengelola pesantren dikenal dengan nama kurikulum kepesantrenan dan Departemen Pendidikan dan Kebudayaan, maka kurikulum nonformal ini hanya bersumber dari pengelola pesantren saja. Adapun mata pelajaran 
kegiatan/latihan yang diusung oleh kurikulum nonformal ini adalah: bina bahasa. ${ }^{51}$

Selanjutnya, pengelola pesantren memasukkan juga kegiatan ekstra kurikuler ke dalam kurikulum nonformal ini. Secara keseluruhan kegiatan ekstra kurikuler dapat dibagi ke dalam empat kategori, yaitu: a. Seni bela diri yang meliputi tae kwon do, wu do kai, dan tapak suci. b. Olahraga yang meliputi sepak bola, bola basket, tenis meja, bola voli, sepak takraw, dan bulu tangkis. c. Kesenian yang meliputi kursus guitar, kursus drumb, drumband, band santri, qasidah rebana, dan vocal group. d. Ketrampilan yang meliputi letter, kaligrafi, komputer, dan jurnalistik. Walaupun kegiatan ekstra kurikuler tersedia begitu banyak pilihan, tetapi ada mekanisme yang berlaku bagi santri, yaitu: Setiap santri tidak diperbolehkan mengikuti seluruh rangkaian kegiatan

\section{Analisis Perubahan Kurikulum Pesantren}

Perubahan kurikulum pesantren yang terjadi di pesantren Ummusshabri sebagai fokus penelitian ini adalah bukti bahwa pesantren sudah menjadi bagian tidak terpisahkan dari sistem pendidikan nasional dapat dilihat dari begitu banyaknya pesantren tradisional yang memodernisasi dirinya menjadi pesantren modern. Dalam kaitan ini perlu disimak tulisan Husni Rahim yang menyatakan bahwa:Pondok pesantren dikenal dengan dua kategori yaitu pondok pesantren salafiyah dan pondok pesantren khalafiyah. Pondok pesantren khalafiyah mengadopsi sistem pendidikan klasikal dengan kurikulum tertata, mengintegrasikan pengetahuan umum. Sedangkan pondok pesantren salafiyah adalah sistem pendidikan non-klasikal dengan metode bandongan dan sorogan dan kajian kitab-kitab klasik (kuning) yang ditulis dalam bahasa Arab oleh ulama-ulama pada abad pertengahan. Perkembangan terakhir tampaknya jenis pesantren salafiyah telah berkurang diperkirakan tinggal 5.512 pondok pesantren salafiyah dari 11.211 pondok pesantren yang ada di Indonesia. $^{52}$

Dari kutipan di atas, dapat dipahami bahwa lebih dari separuh pondok pesantren di Indonesia telah memodernisasi dirinya dengan

\footnotetext{
${ }^{51}$ Selain kegiatan bina bahasa yang dijadwalkan setiap hari (kecuali hari Jumat) yang berlangsung antara jam 05.30-06.00 untuk kelas I, II, III, dan IV dan jam 15.40-16.00 untuk kelas I, terdapat pula bimbingan bahasa per asrama yang berlangsung setiap hari (kecuali hari Jumat) pada jam 20.00-21.30. Sedangkan kegiatan Membaca Alquran yang difokuskan pada seni bacanya berlangsung pada hari Rabu jam 16.00-17.30. Kegiatan yang terakhir ini hanyadiikuti oleh santri yang memiliki bakat dan minat untuk itu.

${ }^{52}$ Husni Rahim, Madrasah dalam Politik Pendidikan di Indonesia, (Jakarta, Logos Wacana Ilmu, 2005), h. 76.
} 
mengadopsi sistem klasikal. Dengan begitu, pengadopsian sistem klasikal sebagai ciri madrasah memicu pesantren bukan hanya mengadopsi sistem klasikal ansich, tetapi bahkan mengakomodasi lembaga madrasah secara utuh sebagai bagian tidak terpisahkan dari pesantren. Model seperti inilah yang terjadi di pesantren Ummusshabri Kendari yang mengakomodasi seluruh kurikulum madrasah, sehingga menghilangkan tradisi kurikulum pesantren yakni kitab kuning yang dianggap ilmunya ulama salaf yang dipercayai kebenarannya. Teori inilah yang menguatkan tesis Karel A. Steenbrink bahwa ketika diperkenalkan lembaga pendidikan yang lebih teratur dan modern, lembaga pendidikan tradisional ternyata tidak begitu laku dan banyak ditinggalkan siswanya. Demikian halnya dengan Clifford Geertz bahwa pesantren akan tetap eksis sepanjang ia mendirikan madrasah yang memuaskan secara religius bagi penduduk dan sekolah yang berfungsi membantu pertumbuhan Indonesia Baru.

Teori Karel A. Steenbrink dan Clifford Geerzt di atas tidak sepenuhnya benar, karena masih banyak pesantren yang melakukan modernisasi tetapi tetap bertahan pada jati diri pesantren tanpa kehilangan esensi dari pesantren itu sendiri. Hal dibuktikan oleh penelitian Ali Anwar yakni Pembeharuan Pendidikan Pesantren Lirboyo di Kediri, ${ }^{53}$ kajian memberi kesimpulan bahwa di pesantren Lirboyo ada Madrasah Diniyah Hidayatul Mubtadi'in dan tetap survive walaupun dihadapkan pada pendidikan yang lebih modern seperti MTs dan MA dan bahkan SD, SMP, SMA ar-Risalah, hal ini disebabkan pada tiga hal: Pertama, lembaga pendidikan tradisional ini masih sesuai dengan kecenderungan sosial-kultural yang mengaggap faham Ahlus Sunnah wal-Jama'ah. Kedua, lembaga pendidikan tradisional ini berhasil mengantar santrinya untuk menguasai kitab kuning. Ketiga, dikarenakan tradisi dan norma yang dikembangkan dengan lestarinya kharisma kyai. Bahkan penelitian ini menemukan bahwa dari 9.163 santri Lirboyo saat ini, $5.720(62,42 \%)$ hanya mendalami kitab kuning di Madrasaha Hidayatul Mubtadi'in. Penelitian tersebut membuktikan bahwa tidak semua pesantren yang melakukan pembaharuan kurikulum harus menghilangkan fungsi utama pesantren, yaitu transmisi ilmu keislaman, pemeliharaan tradisi Islam dan penciptaan kader-kader ulama.

\section{Kesimpulan}

Kajian ini membuktikan bahwa oreintasi perubahan kurikulum pesantren dalam perspektif historis telah dilakukan pesantren Ummushabri Kendari dengan membuka MTS dan MA sebagai sistem

\footnotetext{
${ }^{53}$ Baca Ali Anwar, Pembaharuan Pendidikan di Peantren Lirboyo Kediri, (Yogyakarta, Pustaka Pelajar, 2011), h. 165-166. 
pendidikan modern, namun perubahan itu menyebabkan sistem pendidikan tradisional ditinggalkan siswanya. Karena itu, pendidikan tradisional pesantren telah kehilangan fungsinya sebagai lembaga pesantren, yang justru medominasi adalah kurikulum madrasah dan sekolah umum. Studi ini juga menemukan tidak semua pesantren melakukan perubahan meninggalkan tradisinya, hal ini terlihat pembaharuan pendidikan pesantren Lirboyo yang berhasil mempertahankan fungsi utama lembaga pesantren yakni trasnmisi ilmu pengetahuan keislaman, pemeliharaan tradisi Islam serta penciptaan kader-kader ulama, dan menjadikan model pembaharuan pensantren Lirboyo sebagai perbandingan.

\section{Daftar Pustaka}

Anwar, Ali, Pembaharuan Pendidikan di Peantren Lirboyo Kediri, Yogyakarta, Pustaka Pelajar, 2011.

Azra, Azyumardi, Pendidikan Islam; Tradisi dan Modernisasi Menuju Milenium Baru, Jakarta, Logos Wacana Ilmu, 2000.

Azyumardi Azra, Esei-esei Intelektual Muslim dan Pendidikan Islam, Jakarta: Logos Wacana Ilmu, 1998.

Badan Penelitian dan Pengembangan Agama Depag RI, "Penyusunan Bibliografi Beranotasi tentang Karya Ulama di Sulawesi Tenggara, Tengah \& Utara", Laporan Penelitian (Ujungpandang: Balai Penelitian Lektur Keagamaan Ujungpandang, 1982/1983).

Hasbullah, Sejarah Pendidikan Islam di Indonesia, Jakarta, Raja Grafindo Persada, 1999.

Lesmana, Andre Fellend, NU Vis-a Vis Negeri Pencari Isi, Bentuk dan Makna, Yogyakarta, LKIS, 1999.

Ibrahim, Sulaiman, Pendidikan tentang Manusia dalam Perspektif AlQur'an, Jurnal Ilmiah AL-Jauhari, Vol. 2, No. 2, 2017, h. 145148

Mastuhu, Dinamika Pendidikan Pesantren, Indonesia, Netherlands coorporation in Islamic Studies, seri Inis, XX, Jakarta, 1994.

Nasution , S., Asas-asas Kurikulum, edisi kedua, Jakarta: Bumi Aksara, 1995.

----------, S., Asas-asas Kurikulum, Jakarta: Bumi Aksara, 1995.

Noer, Delier, Gerakan Modern Islam di Indonesia 1900-1942, Jakarta, LP3ES, 1998.

Rahim, Husni, Madrasah dalam Politik Pendidikan di Indonesia, Jakarta, Logos Wacana Ilmu, 2005. 
Ramli, Andi M., Gambaran Singkat tentang Pendidikan di Pesantren, dala Buletin Bina Pesantren, Depag RI, Juli 1999.

Stennbrink, Karel A., Pesantren, Madrasah, Sekolah; Pendidikan Islam dalam Kurun Modern, Jakarta, LP3ES, 1998.

Sukmadinata, Nana Syaodih, Landasan Psikologi Proses Pendidikan, Bandung: PT. Remaja Rosdakarya, 2004.

Suparta, Mundzier, Perubahan Orientasi Pondok Pesantren Salafiyah: Terhadap Perilaku Keagamaan Masyarakat, Jakarta, Asta Buana Sejahtera, 2009.

Undang-undang Rebublik Indonesia No. 20 Tahun 2003 tentang Sistem Pendidikan Nasional (SISDIKNAS), Bandung: Citra Umbara, 2003.

Zamakhsyari Dhofier, Tradisi Pesantren, Jakarta, LP3ES, 2011.

Zarkasyi, Abdullah Syukri, Gontor dan Pembaharuan Pendidikan Pesantren, Jakarta, Rajawali, 2005. 